\title{
Development of a mathematical model to predict pool sizes and rates of digestion of 2 pools of digestible neutral detergent fiber and an undigested neutral detergent fiber fraction within various forages
}

\author{
E. Raffrenato, ${ }^{1,2}$ C. F. Nicholson, ${ }^{3}$ and M. E. Van Amburgh ${ }^{1 *}$ \\ ${ }^{1}$ Department of Animal Science, Cornell University, Ithaca, NY 14853 \\ ${ }^{2}$ Department of Animal Sciences, Stellenbosch University, Stellenbosch, South Africa 7600 \\ ${ }^{3}$ Charles H. Dyson School of Applied Economics and Management, Cornell University, Ithaca, NY 14853
}

\begin{abstract}
The digestion of neutral detergent fiber treated with amylase and sodium sulfite and ash corrected (aNDFom) has been described as a single digestible pool and a fraction undigested in ruminants. Further, most models that predict rate and extent of digestion of aNDFom in the rumen assume first-order processes, in which the rates of digestion and passage are proportional to the pool size of aNDFom consumed and digested. Data exist demonstrating that the undigested fraction of aNDFom is not well described by a fixed coefficient and varies by maturity and agronomic growing conditions of the plant. Thus, our objective was to improve the prediction of digestible aNDFom (pdNDF) and to quantify, using a minimum number of fermentation time points, 2 pools of digestible aNDFom, $\mathrm{pdNDF}_{1}$ and $\mathrm{pdNDF}_{2}$, and their respective rates. Based on fermentations from 0 to $240 \mathrm{~h}$ among 34 forages (grasses, conventional and brown midrib corn silages, and alfalfas), 3 pools were described by aNDFom ${ }_{t}=\operatorname{pdNDF}_{1} \times \mathrm{e}^{-\mathrm{k} 1(\mathrm{t}-\mathrm{L})}+$

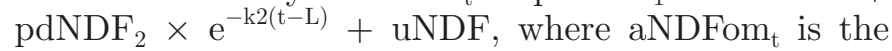
residue at time $t ; \mathrm{L}$ is the lag; $\mathrm{k}_{1}$ is the rate of digestion of $\mathrm{pdNDF}_{1} ; \mathrm{k}_{2}$ is the rate of digestion of $\mathrm{pdNDF}_{2}$; and uNDF the unavailable NDF on an aNDFom basis. A nonlinear estimation allowed the computation of the pool size and respective digestion rates. Using 3 time points from the digestion curve, 30,120 , and $240 \mathrm{~h}$, as the fermentation endpoints to represent uNDF, we optimized the same model in Vensim (Ventana Simulation Environment; Ventana Systems Inc., Belmont, MA) to obtain rates and pool sizes of aNDFom. In addition, the same optimization was also performed with 2 timepoints and a forage type-specific range for uNDF. Parameters (with and without uNDF) obtained per forage using Vensim were compared by fitting kinetics data
\end{abstract}

Received May 22, 2018.

Accepted September 22, 2018.

*Corresponding author: mev1@cornell.edu from the nonlinear calculations, using coefficients of determination and residual mean squares at convergence for ranking purposes for the whole equation and mean squared prediction errors for specific parameters. The highest coefficient of determination (0.98) and lowest mean square prediction error $\left[0.0927\left(\mathrm{NDF}^{-1}\right)^{2}\right]$ were obtained when using 48, 120, and $240 \mathrm{~h}$ of aNDFom residues or when using 30 and $120 \mathrm{~h}$ and a range for the forage-specific uNDFom. Correlations were in all cases consistently high for all kinetic parameters, ranging from 0.76 to 0.99 . Results demonstrated that an adequate description of the heterogeneity of aNDFom disappearance was possible without multiple fermentation time points. The equation was fit to all data generated; however, because of the variable nature of pool sizes and rates, forage-specific equations should be developed for better estimations of the forage specific pool sizes and uNDF estimation. This study further describes the heterogeneous nature of aNDFom disappearance and provides an approach for estimating the individual pool sizes and rates of digestion for application for diet formulation.

Key words: NDF digestibility, modeling, rates of digestion, forages

\section{INTRODUCTION}

Neutral detergent fiber is the most common measure of fiber used for animal feed analysis, but it does not represent a unique or homogeneous class of chemical components. Further, Mertens (2002) published a method treating NDF that included the option of using $\alpha$-amylase and sodium sulfite and correcting for ash contamination (aNDFom). Nutritionally, this is the most useful approach, as it reduces the variation around the measurement and corrects for any contamination that can inflate the NDF content and is the method applied throughout the current study. Heterogeneity of the aNDFom content of a plant can be demonstrated by the Lucas test (Lucas, 1964; Van 
Soest, 1994), and the purpose of the Lucas test was to identify ideal nutritional components that have uniform digestibility over a wide range of feedstuffs by plotting the digestible nutrient concentration in DM against the nutrient concentration in DM. The slope of regression estimates the true digestibility and the intercept is an estimate of the metabolic and endogenous fecal matter. The neutral detergent chemistry divides the feed into a soluble fraction that is rapidly and almost completely available with a digestibility of 0.98 and a fiber fraction that is slowly and incompletely degraded by microbial enzymes (Huhtanen et al., 2006). Furthermore, NDF is also characterized by the presence of a fraction that is indigestible to microbial fermentation in the rumen even if the total-tract residence time of fiber could be extended infinitely (Allen and Mertens, 1988; Van Soest, 1994). As digestibility cannot be extended infinitely, true indigestible NDF is not measured; thus, it is an approximation represented by undigested NDF (UNDF) at particular time points in the fermentation and represents NDF not digestible in the animal. In this case, uNDF is represented by the residue remaining after $240 \mathrm{~h}$ in vitro digestion (Raffrenato et al., 2018); thus, by definition, uNDF represents a uniform feed fraction with zero true digestibility according to the Lucas test (Lucas, 1964). The potentially digestible aNDFom (pdNDF) will then result from the difference NDF minus uNDF.

Although dietary concentration of aNDFom is positively related to bulk density of feeds and affects feed intake potential (Dado and Allen, 1996), forage aNDFom varies in digestibility in the rumen (Allen and Mertens, 1988) and in vitro (Mertens, 1973). Digestibility of aNDFom can influence animal performance independent of dietary aNDFom concentration. In animal trials where forages of higher in vitro digestibility but similar aNDFom concentration have been fed, the authors reported significant increases in DMI and milk production (Grant et al., 1995; Dado and Allen, 1996; Oba and Allen, 2000). Faster disappearance of the NDF fraction from the rumen because of increased rate of digestion or passage will reduce physical fill in the rumen over time and allow greater voluntary feed intake (Mertens, 1994; Van Soest, 1994).

Accurate and precise predictions of the intrinsic digestion kinetic parameters are critical to the estimation of NDF rumen digestibility and intake. The importance of a single fractional rate $\left(\mathbf{k}_{\mathrm{d}}\right)$ and extent of NDF digestion on total-tract $\mathrm{OM}$ and NDF digestibility can be demonstrated by simulation with the Cornell Net Carbohydrate and Protein System model (Fox et al., 1992, 2004; Russell et al., 1992; Sniffen et al., 1992) or with the Nordic model of cow metabolism, "Karoline" (Danfær et al., 2006a,b). Simulation results clearly demon- strate profound effects of these parameters on ruminal and total-tract NDF digestibility, and therefore on the supply of energy and microbial protein (Raffrenato and Erasmus, 2013).

One of the problems in describing digestion kinetics is that residues remaining at any digestion time are a mixture of undigested and indigestible matter (Mertens, 2005). Furthermore, Mertens $(1973,1977)$ and Mertens and Ely (1979) indicated that overall digestion is better predicted assuming that the pdNDF fraction is the sum of 2 digestible fractions that can be described by 2 first-order functions but with different rate constants. According to Van Milgen et al. (1991), the assumption of a single fractional digestion rate constant for NDF is also untenable because of the chemical and morphological diversity of forages fed to livestock. More recently, Ellis et al. (2005) demonstrated an improved fit of a 2-pool pdNDF model that assumed 2 concurrently degrading subentities of pdNDF with different degradation rates. Further, from in vitro gas production and NDF digestion, Huhtanen et al. (2008b) showed a marked improvement of the model when pdNDF was assumed to be composed of rapidly and slowly degradable fractions.

Rate of digestion of aNDFom is an input in the Cornell Net Carbohydrate and Protein System (Tylutki et al., 2008; Van Amburgh et al., 2015). However, more routine incorporation of digestion rates as a standard procedure to calculate the nutritive quality of specific feeds and diets has been achieved only recently, in part because of lengthy laboratory analyses and statistical interpretation of fiber digestion rates. The mathematical approach by Van Soest et al. (2005) described a method for determining the multiple pools and rates of digestion for the pools of pdNDF with multiple time points, assuming first-order behavior and a fixed uNDF pool. The uNDF fraction was estimated using the formula $(\mathrm{ADL} \times 2.4) / \mathrm{NDF}$, where 2.4 was the factor obtained by Chandler et al. (1980). The primary limitation of this approach was related to the use of the value of 2.4, which assumed a fixed relationship between the measured lignin content and NDF digestibility.

Data from Nousiainen et al. $(2003,2004)$ demonstrated that the relationship between lignin and digestibility in grasses was highly variable, which was reinforced by Rinne et al. (2006) in legume forages. However, to achieve this, those authors conducted long-term digestions using an in situ procedure, which is not easily done by a commercial laboratory for routine analysis. More recently, Palmonari et al. (2016) estimated indigestible fiber in various forage types using $240 \mathrm{~h}$ of in vitro digestion, confirming previous results (Nousiainen et al., 2003, 2004; Rinne et al., 2006). In a companion paper (Raffrenato et al., 2018), we demonstrated, 
through improved recoveries and definitions of both ADL and UNDF, that the relationship between uNDF and ADL was more variable than previously assumed (Chandler et al., 1980) and can be measured using a 240-h in vitro method with an appropriate filtration procedure (Raffrenato and Van Amburgh, 2011; Raffrenato et al., 2018). Previously, Krizsan et al. (2012) showed good potential of a technique to associate the near infrared spectra with uNDF obtained by 288 -h in situ fermentations. However, near infrared spectra can be calibrated for uNDF only by an increased range in reference data.

The hypothesis evaluated in our study was that the improved methodology to determine uNDF could result in a better description of pdNDF digestion in multiple pools, which could be accomplished with a minimal number of fermentation points. Therefore, our objective was to predict the proportions of the fast- and slow-degrading pools of aNDFom and their respective fractional digestion rates using $240 \mathrm{~h}$ of fermentation as the endpoint for uNDF and to identify the best and least number of time points necessary for this to be conducted by commercial laboratories. A secondary objective was to assess the accuracy of predicting the same parameters when the uNDF was not available and a forage type-specific range for the ratio of uNDF to ADL was used instead. Finally, we wanted to demonstrate how a single weighted $\mathrm{k}_{\mathrm{d}}$ for the whole pdNDF fraction, from the fast and slow fractions, could be obtained and used when the definition of fast and slow pool was not yet implemented in nutrition model systems. Our approach was to develop composite decay models to describe the heterogeneous behavior of aNDFom digestion.

\section{MATERIALS AND METHODS}

Thirty-four forages, including grasses, conventional as well as brown midrib (BMR) corn silages, and alfalfas, were analyzed in duplicate for NDF and ADL. All samples were ground through a 1-mm screen in a Wiley Mill (Thomas Scientific, Swedesboro, NJ). For the fermentations, $0.75 \mathrm{~g}$ of each sample was weighed into 125-mL Erlenmeyer flasks and inoculated with buffer and rumen fluid from 0 to $240 \mathrm{~h}$ according to Goering and Van Soest (1970) and Van Soest (2015); residues were analyzed for NDF. Rumen fluid was harvested from 2 lactating cows fed a TMR and housed at the Cornell University research farm, which was combined to form the inoculum. Residual ash-free NDF of the fermented samples was obtained at $0,6,12,24,30,36,48$, $72,96,120,144,216$, and $240 \mathrm{~h}$ based on the procedure of Mertens (2002). Observations were taken more often at earlier time points to offset the greater variation that occurs during the first part of the fermentation and digestion of the substrate (Mertens, 2005). We omitted the use of sodium sulfite for the NDF analyses. Blank flasks at each time point were used to correct for any particles introduced from the inoculation with rumen fluid and were analyzed similarly to the samples. A glass microfiber filter (934-AH by Whatman, Whatman Limited, GE Healthcare, Maidstone, UK) was used in all analyses to minimize particle loss and increase recovery, as suggested by Raffrenato and Van Amburgh (2011) and Raffrenato et al. (2018). The time points chosen for the fermentations were based on previous observations and calculations by Van Soest et al. (2005) and Raffrenato et al. (2018), where the time points early in the fermentation were within the linear phases of the log-transformation of the digestion curves describing a fast and slow pool of aNDFom disappearance and the UNDF determined in vitro was apparent by $240 \mathrm{~h}$ of fermentation (Figure 1). All fermentations were replicated twice to ensure adequate description of the forage digestions.

Composite decay models are formed by the sum of several exponential functions and have been used to describe various physical phenomena; the nonlinear least squares fit is the most common method in use to solve them (Villuendas and Pelayo, 1987). Assuming more than one fraction of pdNDF can be described mathematically (Ellis et al., 2005; Van Soest et al., 2005; Huhtanen et al., 2008a), a composite decay model was used to estimate a fast- and a slow-degrading pool and the respective rates of digestion and an undigested fraction. Therefore, the residual NDF at time $t$ was described by:

$$
\begin{aligned}
\mathrm{NDF}_{(\mathrm{t})}= & \operatorname{pdNDF}_{1(0)} \times \mathrm{e}^{-\mathrm{k} 1(\mathrm{t}-\mathrm{L})}+\operatorname{pdNDF}_{2(0)} \\
& \times \mathrm{e}^{-\mathrm{k} 2(\mathrm{t}-\mathrm{L})}+\mathrm{uNDF}
\end{aligned}
$$

where $\operatorname{pdNDF}_{1(0)}$ and $\mathrm{k}_{1}$ are the size at time 0 and the fractional rate of the fast pool, respectively; $\mathrm{pdNDF}_{2(0)}$ and $\mathrm{k}_{2}$ are the size at time 0 and the fractional rate of the slow pool, respectively; $\mathrm{L}$ is the lag time to establish the fermentation; and $\mathrm{uNDF}$ is the undigested NDF. Simultaneous estimations of the parameters $\mathrm{pdNDF}_{1}$, $\operatorname{pdNDF}_{2}, \mathrm{k}_{1}, \mathrm{k}_{2}, \mathrm{uNDF}$, and L were initially obtained using PROC NLIN of SAS (version 9.3, SAS Institute, Inc., Cary, NC) and the Marquardt algorithm. The Marquardt algorithm was selected to improve the efficiency of providing least squares estimation for the nonlinear curve fitting approach. Nonlinear regression was chosen as the procedure because the method assumes equal error at each observation; by simultaneously fitting all parameters to the data, the result provides the smallest residual sums of squared deviations for the model. Due 


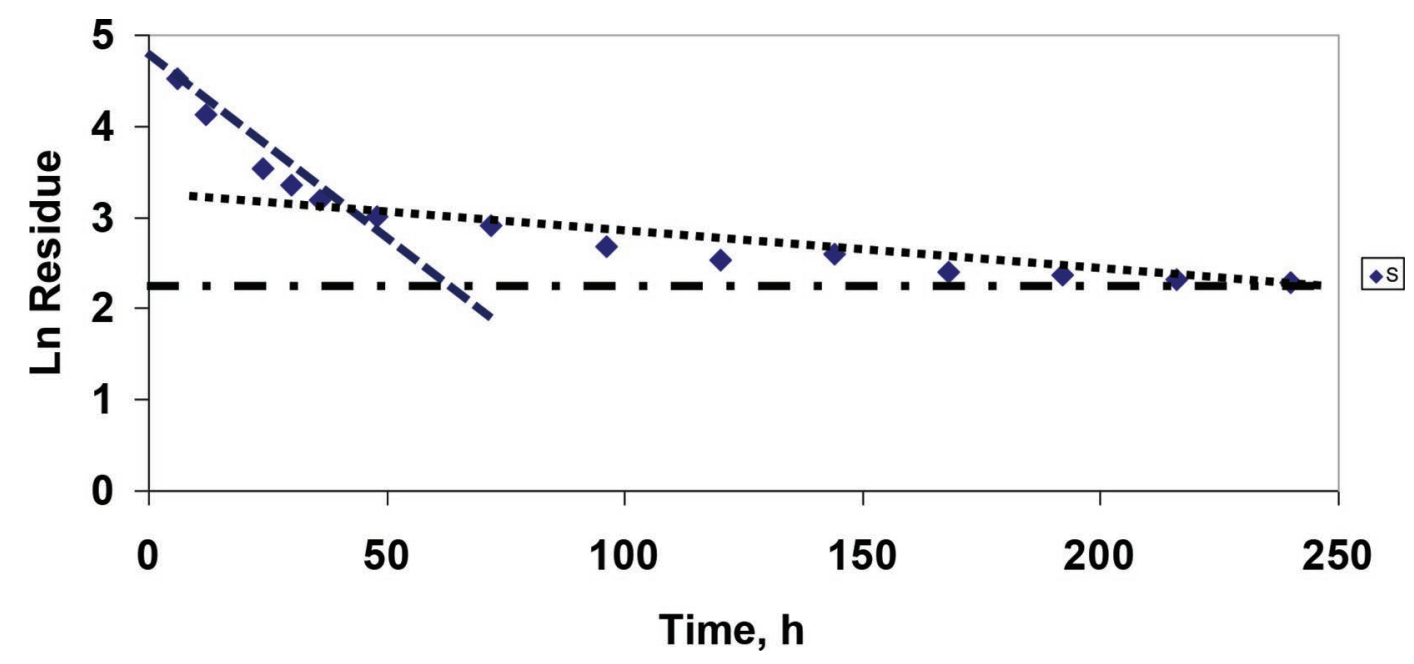

Figure 1. Example showing the partitioning of corn silage NDF into pools and rates using a simple log-transformation of the digestion curve (Ln Residue). In this example, the first pool (- - ) is exhausted by $48 \mathrm{~h}$, as characterized by the inflection, and the second digestible pool (. . ) is exhausted by $240 \mathrm{~h}$, representing the unavailable NDF $(-\cdot-\cdot) . \mathrm{S}=$ substrate, corn silage NDF.

to the large range in digestibility among forages at the early time points, a couple of aspects to the fermentation method can introduce error, including an unknown event that creates an extended fermentation lag time or inflated sample error due to homogeneity or poor recovery. However, the assumption of equal error was made because of the standardization of the procedure and the use of the small pore size filter paper to ensure uniform recovery of very small particles that can be lost in other methods (Uden, 2006; Raffrenato et al., 2018). The necessity of establishing initial parameters values for the nonlinear estimations was solved using a linear approach to seed the nonlinear estimation, as done by Grant and Mertens (1992). We used the loglinear approach of Van Soest et al. (2005) to generate the initial values for each sample to parameterize the composite decay model, including a fast, a slow, and a uNDF pool for model (1) using 240-h residual NDF to estimate the pdNDF. The mathematical approach used here (Van Soest et al., 2005) to obtain initial values was derived from the linearization of the nonlinear firstorder composite decay; therefore, it seems reasonable to make comparisons to this procedure and provides a simple cross-check of procedures, especially to compare the integrated rate of digestion for a first-order model application, as demonstrated in Figure 1.

The statistical model, similar to the nonlinear model described, used all available data observations at different time points and was therefore regarded as more accurate, and perhaps more precise, because it relies on using all of the data points and thus requires the use of the entire decay curve. However, use of statistical models would require significant effort by a commercial laboratory, and development of an inexpensive and less labor-intensive approach for routine measurements for field nutritionists would be beneficial. Therefore, prediction of $3 \mathrm{NDF}$ fractions with the least possible number of fermentation points for use in commercial laboratories was an objective.

Vensim (Ventana Simulation Environment; Ventana Systems Inc., Belmont, MA) is an interactive software environment that allows the development, exploration, analysis, simulation, and optimization of dynamic models. A model was built and run in Vensim 5.5 (Ventana Simulation Environment; Ventana Systems Inc.) with calculation intervals of $0.0625 \mathrm{~h}$ and initial and final time points of 0 and $240 \mathrm{~h}$, respectively. The Vensim modeling language works with the concept of stocks (pools) and flows (disappearance or digestion), and this terminology will be interspersed in this paper. The model (Figure 2) does not require all the data points required of the statistical model and allows the use of fewer data points to estimate the desired parameters. Furthermore, it is structurally consistent with conservation of mass and thus avoids negative values for the stocks or pools that might occur for the unconstrained statistical model.

The structure in the model (Figure 2) of the slow pool stock (SPS) depicts a goal-seeking behavior, with the goal in this case being represented by the uNDF. The slow-degrading pool is calculated as $\mathrm{pdNDF}_{2}=$ $1-\left(\operatorname{pdNDF}_{1}+\mathrm{uNDF}\right)$. Furthermore, the model was parameterized by the condition: if $0 \leq \mathrm{t} \leq \mathrm{L}$, then $\mathrm{NDF}_{\mathrm{t}}=\mathrm{pdNDF}_{1(0)}+\mathrm{pdNDF}_{2(0)}+\mathrm{uNDF}$; otherwise equation 1 was applied (Mertens and Loften, 1980; Moore and Cherney, 1986). We took these steps to 


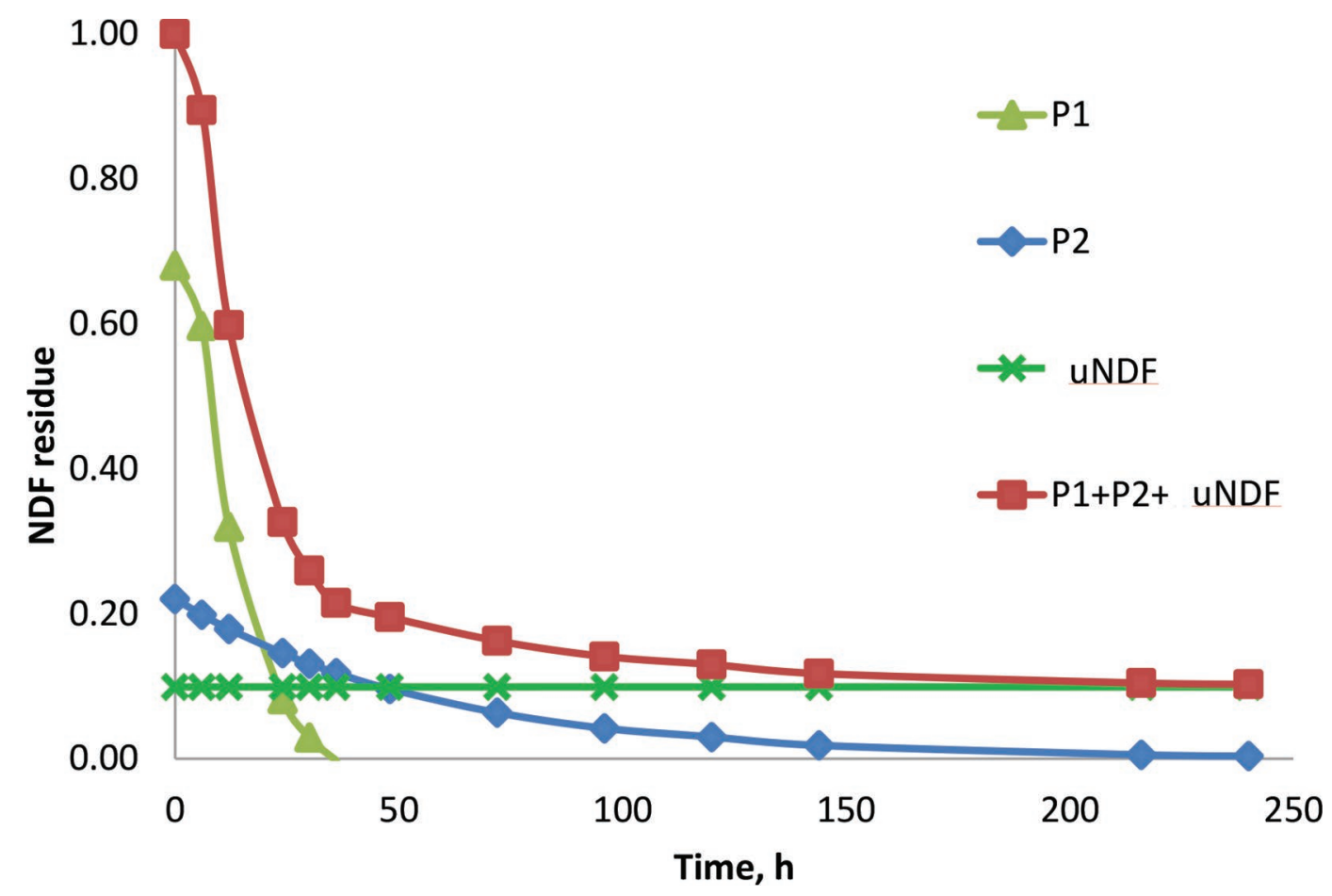

Figure 2. The residual NDF of a corn silage after in vitro fermentation, from 0 to $240 \mathrm{~h}$, with the total NDF disappearance and the calculated amounts of the faster (P1) and the slower (P2) pool of digestible NDF and the unavailable NDF (uNDF) measured at $240 \mathrm{~h}$ of in vitro digestion and pool sizes calculated using the measured uNDF in place of the static calculation of lignin $\times 2.4 / \mathrm{NDF}$.

avoid having a separate nonlinear model for $\mathrm{t} \leq \mathrm{L}$, assuming the stabilization of the fermentation was at $t$ $=\mathrm{L}$. Concentrations were expressed in terms of fraction of the initial NDF. The system of differential equations for the model depicted in model 2, with fast pool stock (FPS) and SPS:

$$
\begin{gathered}
\mathrm{t}<\mathrm{L}, \text { then } \mathrm{dFPS}_{1} / \mathrm{dt}=0 \text { and } \mathrm{dSPS}_{2} / \mathrm{dt}=0 ; \\
\mathrm{duNDF} / \mathrm{dt}=0 \\
\mathrm{t} \geq \mathrm{L}, \text { then } \mathrm{dFPS} / \mathrm{dt}=-\mathrm{k}_{1} \mathrm{FPS} \\
\mathrm{dSPS} / \mathrm{dt}=-\mathrm{k}_{2}(\mathrm{SPS}-\mathrm{uNDF}) \\
\text { and duNDF } / \mathrm{dt}=0
\end{gathered}
$$

The model performs calculations based on the equivalent integral equations, which are given by

$$
\begin{gathered}
\mathrm{t}<\mathrm{L}, \text { then } \mathrm{FPS}_{(\mathrm{t})}=\mathrm{FPS}_{(0)}, \\
\mathrm{SPS}_{(\mathrm{t})}=\mathrm{SPS}_{(0)}, \\
\mathrm{uNDF}_{(\mathrm{t})}=\mathrm{uNDF}_{0},
\end{gathered}
$$
[8] pool, slow pool, indigestible fraction), a point between

$$
\begin{aligned}
& \text { with } \mathrm{SPS}_{(0)}=1-\mathrm{FPS}_{(0)}-\mathrm{uNDF}_{(0)} \\
& \text { and, thus, } \mathrm{NDF}_{(\mathrm{t})}=\mathrm{pdNDF}_{1(0)} \\
& +\mathrm{pdNDF}_{2(0)}+\mathrm{uNDF}_{0} .
\end{aligned}
$$

At $\mathrm{t} \geq \mathrm{L}$, then $\mathrm{FPS}_{(\mathrm{t})}=\operatorname{pdNDF}_{1} \exp \left[-\mathrm{k}_{1}(\mathrm{t}-\mathrm{L})\right]$,

$$
\begin{aligned}
\mathrm{SPS}_{(\mathrm{t})} & =\operatorname{pdNDF}_{2} \exp \left[-\mathrm{k}_{2}(\mathrm{t}-\mathrm{L})\right] \\
& +\mathrm{uNDF}_{(\mathrm{t})}=\mathrm{uNDF}_{(0)}
\end{aligned}
$$

and, thus, $\mathrm{NDF}_{(\mathrm{t})}=\operatorname{pdNDF}_{1(\mathrm{t})}+\operatorname{pdNDF}_{2(\mathrm{t})}$

$$
+\mathrm{uNDF}_{(\mathrm{t})}=\operatorname{pdNDF}_{1(0)} \exp \left[-\mathrm{k}_{1}(\mathrm{t}-\mathrm{L})\right]
$$$$
+\operatorname{pdNDF}_{2(0)} \exp \left[-\mathrm{k}_{2}(\mathrm{t}-\mathrm{L})\right]+\mathrm{uNDF}_{(0)} \text {. }
$$

Optimization methods can be used to estimate parameters of this model. In our procedure, optimizations were run using residues at different fermentation time points, and the choice of the time points was made by evaluating the time points that represented the 3 fractions with the least amount of error. Previous work by Van Soest et al. (2005; Figure 1) showed that the fast pool was exhausted by $48 \mathrm{~h}$; thus, we chose a time point up to $48 \mathrm{~h}$ to represent the first part of the curve (fast 
48 and $216 \mathrm{~h}$ to represent the second part of the curve (slow pool and the indigestible fraction), and $240 \mathrm{~h}$ to represent the uNDF fraction (Raffrenato et al., 2018). All combinations of the points available $(6,12,24,30$, 36 , and $48 \mathrm{~h}$ for the fast pool; 72, 96, 120, 144, and 216 $\mathrm{h}$ for the slow pool) and $240 \mathrm{~h}$ for the uNDF resulted in 31 possible combinations to be examined. For evaluation of all fractions, it was important to identify time points that were represented in the linear phase of the digestion decay, where solutions provided the lowest mean square error of the prediction. This provided 5 time points early in the fermentation period plus $48 \mathrm{~h}$ to allow for determining an optimum for the fast pool.

A modified Powell hill-climbing algorithm (Powell, 1964) was used to perform the search for the parameter optimization as defined in Vensim 5 Reference Manual (Ventana Systems Inc.). To optimize we defined a payoff, which is a single number reported for each simulation. The NDF residue from 0 to $240 \mathrm{~h}$ was chosen as the payoff because this is a function of the parameters that need to be estimated in the model (i.e., FPS and decay rate, SPS and decay rate, lag, and uNDF). The optimization chooses parameter values that minimize the sum of squared differences between the actual data points and the model predictions for the NDF residue value. Maximizing the payoff means reaching a value as close to zero for the squared difference, and this procedure is similar to regression analysis but with additional constraints on the model structure and, therefore, the parameter values. Parameters of the model that were optimized for were $\mathrm{L}, \mathrm{pdNDF}_{1}, \mathrm{pdNDF}_{2}, \mathrm{k}_{1}$, $\mathrm{k}_{2}$, and $\mathrm{uNDF}$.

The range of values for parameters was constrained as $0<\mathrm{uNDF}<\mathrm{uNDF}_{(240)}$, with $\mathrm{uNDF}_{(240)}$ being the undigested fraction estimated as the residual NDF at $240 \mathrm{~h}$ from the laboratory observation for each forage fermented and $1.5<\mathrm{L}<4.5$ based on the results from the nonlinear estimation in SAS (SAS Institute Inc.) and on our previous work (Van Amburgh et al., 2003). The constraint of $240 \mathrm{~h}$ was chosen based on our previous work (Raffrenato et al., 2018). Optimizations were run for individual forages and values in Vensim of fractional tolerance and tolerance multipliers were left as default values (i.e., 0.0003 and 21 , respectively), which means the model will attempt to solve the nonlinear extrapolation within $0.03 \%$ of the actual values with a range of $\pm 0.063 \%$.

To determine the optimal time points from the fermentation curve among all combinations, constants obtained from the optimization with Vensim were compared with the values obtained with the nonlinear estimation from equation 1 from PROC NLIN in SAS (SAS Institute Inc.). To evaluate the performance of the optimizations, the goodness of fit was compared using the variance accounted for $\left(\mathrm{R}^{2}\right)$ and the residual mean squares (RMS) at convergence for ranking purposes for each optimal combination of time points. This was done as in Ellis et al. (2005) and Huhtanen et al. (2008a), using the average values obtained by pooling all forages analyzed and then by forage type (conventional and BMR corn silages, grasses, straws and hays, and alfalfas). For each combination, the evaluation was then made separately for each parameter $\left(\mathrm{pdNDF}_{1}\right.$, $\operatorname{pdNDF}_{2}, \mathrm{k}_{1}, \mathrm{k}_{2}, \mathrm{~L}$, and $\mathrm{uNDF}$ ) predicted by the optimization and computations were made as suggested by Piñeiro et al. (2008), with the results of the nonlinear estimation being the observed values, as we assume those to be the most accurate and precise values.

The mean square prediction error (MSPE) was divided into components resulting from mean bias, slope bias, and random or unexplained variation around the regression line according to analysis of Theil (1966) and Bibby and Toutenburg (1977). Significance of the deviation of the intercept from 0 and the slope from 1 was analyzed by $t$-test.

Finally, to make this approach more applicable to commercial laboratories, an analysis and estimation of extent of NDF digestion and UNDF was conducted using forage family-specific endpoints for uNDF as a starting point, knowing there is a range in the uNDF value within and between forage families and the possibility exists that a laboratory might not have or would generate $240-\mathrm{h}$ uNDF values. Therefore, assuming that the residue at $240 \mathrm{~h}$ represents the true uNDF fraction for application in ruminant nutrition and model calculations, we defined specific ranges of the ratios of $\mathrm{uNDF}$ to $\mathrm{ADL}$ for each forage type and determined the range and variance associated with the uNDF value within our data set. The same evaluation using Vensim as described above was then performed using these specific ranges to determine the time points needed to predict the same parameters. The uNDF was then constrained to fall within the range defined for each forage type, based on the ADL-to-NDF ratio. The ratios of uNDF to ADL were constrained as 3.0 to 5.5 for conventional corn silages, 2.0 to 6.5 for BMR corn silages, 2.0 to 6.0 for grasses, and 2.0 to 3.0 for alfalfa forages (Raffrenato et al., 2018). The other constraints were as previously described. Goodness of fit was evaluated as mentioned when using $240 \mathrm{~h}$ as observed uNDF. Within the structure of Vensim, an iterative solution can be used to solve a goal-seeking model and, in this model, the UNDF was added to the SPS as the goal to be identified; this goal is only to provide the pool size, as the uNDF represents the undigested aNDFom for the slow pool. The indigestible fraction is in this case determined by constraining the optimization using the forage type-specific ratio of $\mathrm{UNDF}$ to $\mathrm{ADL}$ and $\mathrm{ADL}$ 
Table 1. Mean values of NDF (\% of DM), ADL ( $\mathrm{g} / \mathrm{kg}$ of NDF), and unavailable NDF ( $\mathrm{uNDF}, \mathrm{g} / \mathrm{kg}$ of NDF) determined after $240 \mathrm{~h}$ of fermentation, and the calculated ratios of uNDF/ADL and respective ranges of the forages used in the analyses per group of conventional and brown midrib corn silages (CS), grasses, and alfalfas (ranges in parentheses) ${ }^{1}$

\begin{tabular}{lccrcc}
\hline Group & Samples & NDF & ADL & uNDF & \multicolumn{1}{c}{ uNDF/ADL } \\
\hline Conventional CS & 8 & 44.04 & 68.6 & 232.4 & $3.38(3.23-5.46)$ \\
Brown midrib CS & 7 & 39.06 & 34.2 & 123.2 & $3.60(2.14-5.78)$ \\
Grasses & 6 & 64.03 & 80.9 & 286.3 & $3.53(2.59-6.53)$ \\
Straws and hays & 6 & 77.25 & 90.0 & 343.2 & $3.45(2.60-4.39)$ \\
Alfalfa silages and hay & 7 & 36.64 & 169.1 & 428.2 & $2.53(2.43-2.95)$ \\
\hline
\end{tabular}

${ }^{1}$ The grasses analyzed were 2 rye grasses, 1 mixed grass, and 3 different timothy grasses of varying NDF content. For the straws and hay, we used 3 wheat straws, 2 orchard grasses, and 1 oat straw.

(both on NDF basis) specific for the individual forage optimized. Optimizations were run in the same manner described above for the model using $240 \mathrm{~h}$ as the endpoint of the fermentation. Finally, Pearson correlation coefficients were determined between all the time points of NDF values from 6 to $240 \mathrm{~h}$ to evaluate the relationships among the time points especially in the later fermentation times where less digestible aNDFom was available.

\section{RESULTS AND DISCUSSION}

Descriptive values of the forages by type are found in Table 1. The nonlinear model resulted in high average coefficient of determination $\left(\mathrm{R}^{2} ;>0.98\right)$ for all forages, and the average values of pool sizes and fractional rates obtained from the nonlinear estimation are shown in Table 2. The values from this nonlinear statistical model are considered the averages of observed values and are used to compare the Vensim outputs. The standard errors of all parameter values were small, ranging from 1.6 to $2.1 \%$ of the mean value, except for $\mathrm{L}$ $(8.1 \%)$. An overall rate of digestion for the whole-feed NDF was obtained from the weighted average of the 2 pdNDF pools. The pools sizes and rates obtained from the nonlinear estimation allowed the extrapolation of the residual pools (example in Figure 3) for the entire curve, and we observed that residues of $\mathrm{pdNDF}_{1}$ are exhausted in most cases by $48 \mathrm{~h}$ and always by
$72 \mathrm{~h}$ of fermentation; this means that the fast pool (pdNDF1) was exhausted between 48 and $72 \mathrm{~h}$ for all forages analyzed, confirming the previous data (Van Soest et al., 2005). Forages, such as BMR corn silages, younger grasses, and alfalfa forages, exhausted their fast pool earlier ( 36 to $48 \mathrm{~h}$ ) in the fermentation curve when compared with conventional corn silages and more mature grasses. In addition, it was apparent that all of the forages analyzed demonstrated a similar pattern of digestibility related to the concept of fast, slow, and unavailable, as observed in Figure 4. Although the terms fast and slow are relative to each other, it is possible that the shift from fast to slow described the carbohydrates cross-linked with the lignin and blocked the degree of access of the microbes for digestion; thus, as the cross-linking increases, the sizes of the 2 pools and their rates of digestion coincide (Raffrenato et al., 2017). An example of this is the relationships of fast and slow pools and the size of the uNDF pool in conventional versus BMR corn silages, where the $\mathrm{uNDF}$ is smaller for BMR, which translates directly into a larger fast pool; this would help explain why BMR forage allows for greater intake at similar inclusion levels in diets (Oba and Allen, 2000).

Based on average $\mathrm{R}^{2}$ across forages, the combinations 48-96-240, 36-120-240, and 48-120-240 h provided the best fit from the model. When compared with the observed values from the nonlinear procedure in SAS, parameters were predicted with a different goodness

Table 2. The pool sizes and rates of digestion ( $\mathrm{k}_{\mathrm{d}}$, per hour) obtained from the simultaneous nonlinear estimation for the respective NDF digestion components ${ }^{1}$

\begin{tabular}{|c|c|c|c|c|c|c|c|}
\hline Type & $\mathrm{n}$ & $\mathrm{pdNDF}_{1}$ & $\mathrm{pdNDF}_{2}$ & $\begin{array}{l}\text { Unavailable } \\
\text { NDF }\end{array}$ & $\mathrm{k}_{1}$ & $\mathrm{k}_{2}$ & $\mathrm{k}_{\mathrm{d}}$ \\
\hline Conventional corn silage & 8 & $0.607(0.031)$ & $0.187(0.032)$ & $0.206(0.012)$ & $0.073(0.005)$ & $0.016(0.006)$ & $0.060(0.004)$ \\
\hline Brown midrib corn silage & 7 & $0.738(0.026)$ & $0.131(0.028)$ & $0.131(0.016)$ & $0.087(0.007)$ & $0.024(0.012)$ & $0.078(0.005)$ \\
\hline Straws and hays & 6 & $0.587(0.024)$ & $0.103(0.023)$ & $0.323(0.041)$ & $0.040(0.006)$ & $0.007(0.003)$ & $0.035(0.004)$ \\
\hline Alfalfas & 7 & $0.487(0.049)$ & $0.087(0.034)$ & $0.425(0.063)$ & $0.134(0.018)$ & $0.024(0.012)$ & $0.113(0.013)$ \\
\hline
\end{tabular}

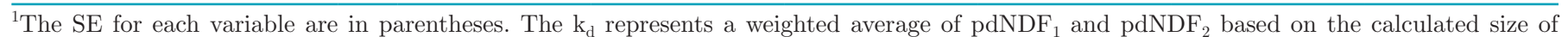
the respective pools (and the $\mathrm{k}_{\mathrm{d}}$ of unavailable NDF is equal to zero by definition), where pdNDF ${ }_{1}$ is the potentially digestible NDF fast pool, $\mathrm{pdNDF}_{2}$ is the potentially digestible slow pool, both defined as a percent of the total potentially digestible NDF. 


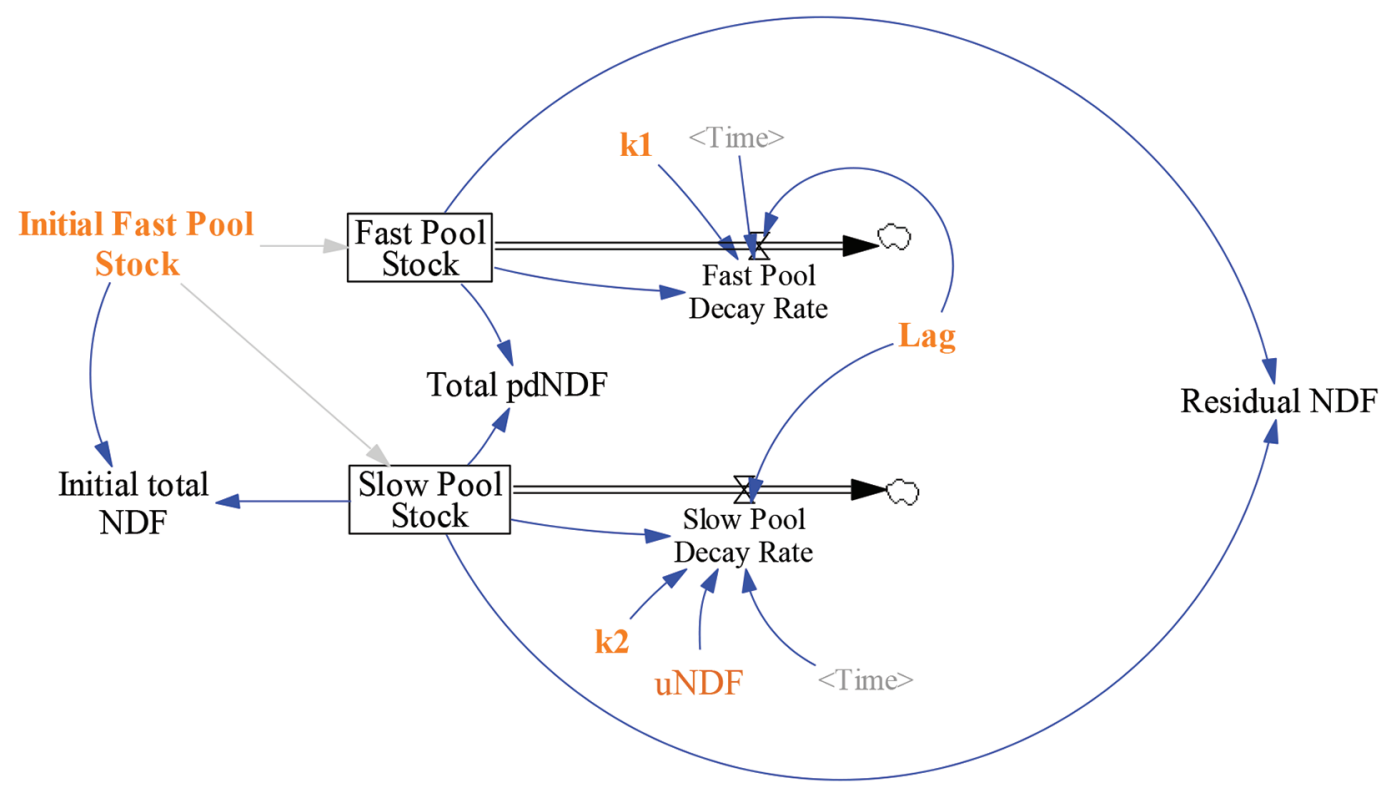

Figure 3. Diagrammatic representation of the composite decay model described in the text. The slow pool stock is in this case equal to $\mathrm{pdNDF}_{2}+$ unavailable NDF (uNDF), and the slow-degrading pool follows a goal-seeking behavior with the goal being uNDF. In orange are

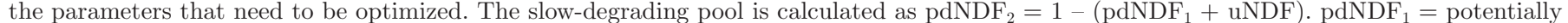
digestible $\mathrm{NDF}$ fast pool; $\mathrm{pdNDF}_{2}=$ potentially digestible slow pool; $\mathrm{k}_{1}=$ digestion rate in percent per hour of the fast pool; $\mathrm{k}_{2}=$ digestion rate of the slow pool.

of fit and precision, resulting in different MSPE. The differences among the combinations of time points and how the MSPE ranked the combinations differently across predicted parameters $\left(\mathrm{pdNDF}_{1}, \mathrm{pdNDF}_{2}, \mathrm{k}_{1}, \mathrm{k}_{2}\right.$, and $\mathrm{uNDF}$ ) are in Table 3.

The parameter values from the optimization in Vensim, using the time point combinations previously identified, and the estimated values from the nonlinear procedure were highly correlated $(P<0.01)$ and ranged in correlation between 0.88 and $0.99,0.53$ and 0.99 , and 0.89 and 0.99 for the combinations 36-120-240, 48-120-240, and 48-96-240 h, respectively. The highest correlations resulted from the direct use of the $\mathrm{uNDF}$ fraction in the model $(240 \mathrm{~h})$, with values of

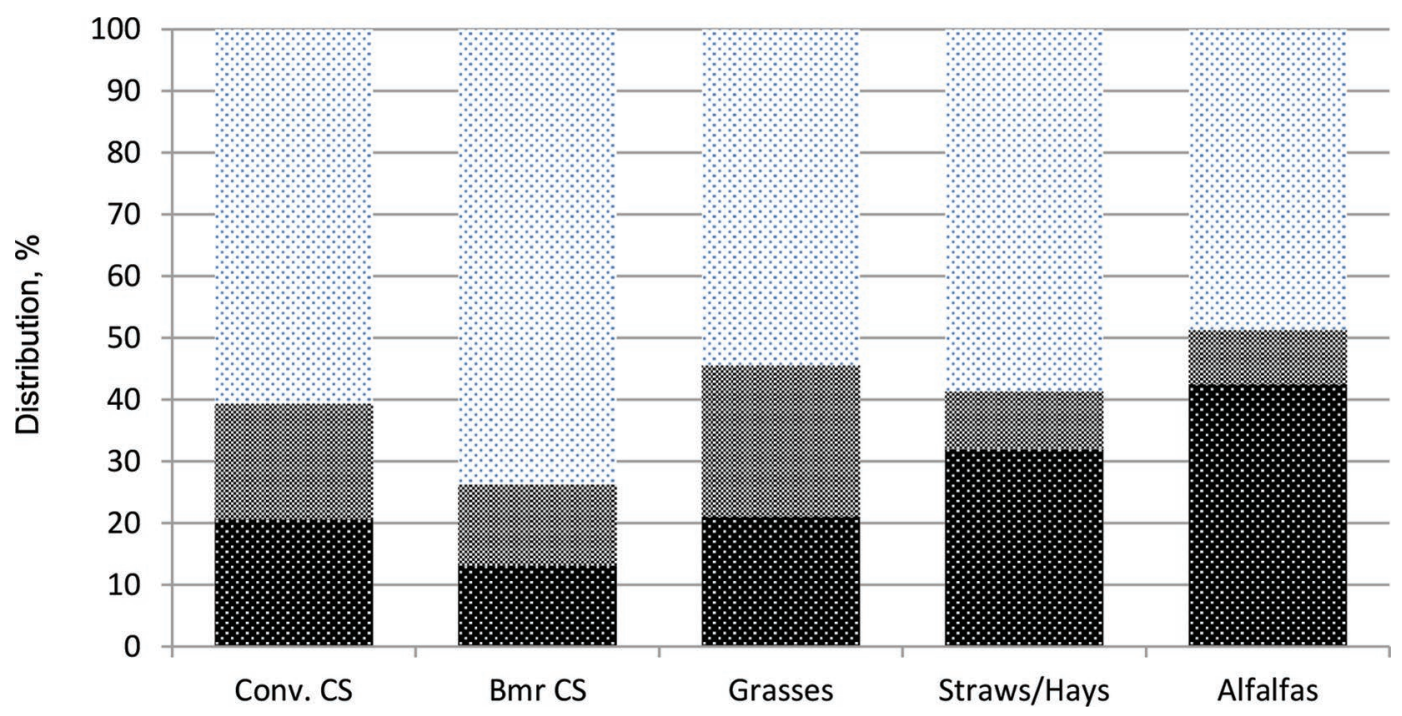

Figure 4. The average distribution, per forage type, of the fast $\left(\mathrm{pdNDF}_{1}\right.$, top light dotted bars) and slow (pdNDF ${ }_{2}$, middle darker shaded bars) pools and unavailable NDF (uNDF, black dotted bottom section) fractions of the forages analyzed. Conv. CS = conventional corn silage; Bmr CS = brown midrib corn silage. 
Table 3. Mean squared prediction errors ${ }^{1}$ for the combinations 48 to 96, 36 to 120 , and 48 to $120 \mathrm{~h}$ as intermediate points, and $240 \mathrm{~h}$ as an endpoint (unavailable NDF), when pooling all forages using the model defined in Vensim (Ventana Simulation Environment; Ventana Systems Inc., Belmont, MA)

Time point combinations

\begin{tabular}{lccc}
\cline { 2 - 4 } Parameter $^{2}$ & $48-96$ & $36-120$ & $48-120$ \\
\hline pdNDF $_{1}$ & 0.1673 & 0.2205 & 0.0927 \\
kdNDF $_{2}$ & 0.1188 & 0.1762 & 0.0948 \\
$\mathrm{k}_{1}$ & 0.0034 & 0.0051 & 0.0029 \\
$\mathrm{k}_{2}$ & 0.0004 & 0.0011 & 0.0039 \\
Unavailable NDF & 0.0219 & 0.0192 & 0.0184 \\
\hline
\end{tabular}

${ }^{1} \mathrm{NDF}^{-1}$ for $\mathrm{pdNDF}_{1}, \mathrm{pdNDF}_{2}$ and unavailable NDF; $\mathrm{h}^{-1}$ for $\mathrm{k}_{1}$ and $\mathrm{k}_{2}$. ${ }^{2} \mathrm{pdNDF}_{1}=$ potentially digestible NDF fast pool; $\mathrm{pdNDF}_{2}=$ potentially digestible slow pool; unavailable NDF $=$ undigested NDF after $240 \mathrm{~h}$ of in vitro fermentation; $\mathrm{k}_{1}=$ digestion rate of the fast pool in percent per hour; $\mathrm{k}_{2}=$ digestion rate of the slow pool.

0.99 between the observed uNDF from PROC NLIN and the predicted uNDF from the Vensim optimizations. The prediction of the lag resulted in low correlations $(\mathrm{r}<0.40)$ with the observed values $(P<0.05)$ and consistently high MSPE for all combinations and is omitted from the tables. The average value of the lag estimated by the nonlinear composite decay, per forage type, ranged from 1.7 to $3.1 \mathrm{~h}$, with the lowest values for alfalfas and the highest values for straws and hays. This inability to predict the lag was most likely due to the lack of a time point early enough in the fermentation to provide sufficient information to the optimizer to estimate the lag. However, imprecise prediction of the lag does not affect the estimates for the other parameters if the lag is constrained within a reasonable range of observed values during the optimization. In our laboratory procedure, the lag was consistently less than $1.5 \mathrm{~h}$, depending on the forage and rate of hydration at incubation.
Although analysis with these time point combinations resulted in parameters describing the data equally well, our objective was the description of the kinetics of NDF digestion that could be used by commercial laboratories with a minimum of time points; therefore, the analysis of the bias in the actual values of the parameters obtained from the calculation method was important for proper application. Pool sizes and rates of digestion were evaluated for their prediction accuracy and biological relevance, with the preferred prediction having a small regression bias and minimal unexplained variation. The prediction of the pool sizes resulting in the lowest MSPE values were for the 48 to $120 \mathrm{~h}$ combination (Table 3 ); he prediction of the rates resulted instead in MSPE equal or less than $0.000051(1 / \mathrm{h})^{2}$. Lastly, the prediction of the uNDF was characterized by a very low MSPE, between 0.000184 and 0.000219 $\left(\mathrm{NDF}^{-1}\right)^{2}$. The specific relationships between the predicted and observed parameter values, the MSPE, and respective distributions are shown in Tables 4, 5, and 6 . The $\mathrm{R}^{2}$ from all regressions of observed on predicted parameters were consistently high, except for the $\mathrm{k}_{2}$ of the 48 to $120 \mathrm{~h}$ combination (0.29; Table 5). However, all other parameters resulted in $\mathrm{R}^{2}$ numerically higher than 0.76 . Precision of the 48 to $120 \mathrm{~h}$ combination is, therefore, less than the other combinations for the prediction of $\mathrm{k}_{2}$ only, and this was confirmed by the slope being different than $0(P<0.05$; Table 5$)$. Both the 36 to 120 and 48 to $120 \mathrm{~h}$ combinations overpredicted the size of pdNDF $_{1}$ by about $10 \%$ of the total NDF; however, slopes were not statistically different than 1 $(P>0.05$; Tables 4 and 5). Predictions from the 48 to $96 \mathrm{~h}$ combination instead resulted in intercepts not different than zero and slopes not different than 1 for all parameters predicted, with $\mathrm{R}^{2}$ between 0.76 and 0.98 (Table 6). The distribution of the MSPE was similar among predicted parameters, with random variation

Table 4. Relationship between the predicted and observed model parameters, mean bias (observed - predicted), mean squared prediction error (MSPE) per parameter, and respective distribution when using 36 and $120 \mathrm{~h}$ as intermediate fermentation time points and $240 \mathrm{~h}$ as the endpoint (unavailable NDF)

\begin{tabular}{|c|c|c|c|c|c|c|c|c|}
\hline Parameter $^{1}$ & Intercept & Slope & $\mathrm{R}^{2}$ & Mean bias ${ }^{2}$ & $\mathrm{MSPE}^{3}$ & \multicolumn{3}{|c|}{ Distribution of MSPE } \\
\hline $\operatorname{pdNDF}_{1}$ & 0.120 & 0.848 & 0.83 & 0.0278 & 0.2205 & 0.350 & 0.080 & 0.570 \\
\hline $\mathrm{k}_{1}$ & 0.002 & 0.924 & 0.87 & -0.0039 & 0.0051 & 0.297 & 0.031 & 0.672 \\
\hline $\mathrm{k}_{2}$ & 0.001 & 0.755 & 0.77 & -0.0017 & 0.0011 & 0.248 & 0.204 & 0.548 \\
\hline Unavailable NDF & -0.013 & 1.023 & 0.98 & -0.0067 & 0.0192 & 0.236 & 0.026 & 0.740 \\
\hline
\end{tabular}

${ }^{1} \mathrm{pdNDF}_{1}=$ potentially digestible NDF fast pool; $\mathrm{pdNDF}_{2}=$ potentially digestible slow pool; unavailable NDF $=$ undigested NDF after $240 \mathrm{~h}$ of in vitro fermentation; $\mathrm{k}_{1}=$ digestion rate of the fast pool in percent per hour; $\mathrm{k}_{2}=$ digestion rate of the slow pool.

${ }^{2} \mathrm{NDF}^{-1}$ for $\mathrm{pdNDF}_{1}$, pdNDF 2 , and unavailable NDF; $\mathrm{h}^{-1}$ for $\mathrm{k}_{1}$ and $\mathrm{k}_{2}$.

${ }^{3}\left(\mathrm{NDF}^{-1}\right)^{2} \times 10^{2}$ for pdNDF $1, \mathrm{pdNDF}_{2}$, and unavailable NDF; $\left(\mathrm{h}^{-1}\right)^{2} \times 10^{2}$ for $\mathrm{k}_{1}$ and $\mathrm{k}_{2}$. 
Table 5. Relationship between the predicted and observed model parameters, mean bias (observed - predicted), mean squared prediction error (MSPE) per parameter, and respective distribution when using 48 and $120 \mathrm{~h}$ as intermediate fermentation time points and $240 \mathrm{~h}$ as the endpoint (unavailable NDF)

\begin{tabular}{|c|c|c|c|c|c|c|c|c|}
\hline Parameter $^{1}$ & Intercept & Slope & $\mathrm{R}^{2}$ & Mean bias ${ }^{2}$ & $\mathrm{MSPE}^{3}$ & \multicolumn{3}{|c|}{ Distribution of MSPE } \\
\hline $\mathrm{pdNDF}_{1}$ & $0.101^{4}$ & 0.851 & 0.89 & 0.0074 & 0.0927 & 0.060 & 0.193 & 0.748 \\
\hline $\mathrm{k}_{1}$ & 0.002 & 1.013 & 0.92 & -0.0032 & 0.0029 & 0.358 & 0.001 & 0.641 \\
\hline $\mathrm{k}_{2}$ & 0.003 & $0.473^{5}$ & 0.29 & -0.0030 & 0.0039 & 0.231 & 0.255 & 0.514 \\
\hline Unavailable NDF & -0.013 & 1.020 & 0.98 & -0.0049 & 0.0184 & 0.123 & 0.020 & 0.850 \\
\hline
\end{tabular}

${ }^{1} \mathrm{pdNDF}_{1}=$ potentially digestible NDF fast pool; $\mathrm{pdNDF}_{2}=$ potentially digestible slow pool; unavailable NDF = undigested NDF after $240 \mathrm{~h}$ of in vitro fermentation; $\mathrm{k}_{1}=$ digestion rate of the fast pool in percent per hour; $\mathrm{k}_{2}=$ digestion rate of the slow pool.

${ }^{2} \mathrm{NDF}^{-1}$ for $\mathrm{pdNDF}_{1}, \mathrm{pdNDF}_{2}$, and unavailable NDF; $\mathrm{h}^{-1}$ for $\mathrm{k}_{1}$ and $\mathrm{k}_{2}$.

${ }^{3}\left(\mathrm{NDF}^{-1}\right)^{2} \times 10^{2}$ for $\mathrm{pdNDF}_{1}, \mathrm{pdNDF}_{2}$, and unavailable NDF; $\left(\mathrm{h}^{-1}\right)^{2} \times 10^{2}$ for $\mathrm{k}_{1}$ and $\mathrm{k}_{2}$.

${ }^{4}$ Intercept significantly $(P<0.05)$ different from 0 .

${ }^{5}$ Slope significantly $(P<0.05)$ different from 1 .

among the regression coefficients providing the greatest contribution to the total MSPE $(>50 \%)$ for all 3 combinations and all parameters. In general, the rest of the MSPE was shared between bias and slope variation.

To test the effect of not using the measured uNDF $(240 \mathrm{~h})$, the optimizer was constrained to forage typespecific ranges for $\mathrm{UNDF}$, and this procedure resulted in an overall lower average RMS and higher $\mathrm{R}^{2}$ for the 30 to 120 and 36 to $120 \mathrm{~h}$ combinations. Under these conditions, the 36 - $\mathrm{h}$ time point did not provide the best solution, as previously observed. The outcome demonstrated that the indigestible portion was efficiently estimated, even without the 240 -h end point, and the optimization was able to explain $97 \%$ of the variation when using 30 and $120 \mathrm{~h}$ as time points (Table 7) and 90\% when using 36 and $120 \mathrm{~h}$ (Table 8). Again, MSPE was mainly the result of unexplained variation for all predicted parameters (Tables 7 and 8).

The optimization of the lag values resulted in the lowest correlations; however, these were still significant $(P<0.05)$, with the highest MSPE, confirming a lack of information for the optimizer. The estimation of uNDF was therefore more important than the estimation of the lag in the prediction of the other parameters of a decay model. This suggests that a better understanding and definition of ranges for uNDF within a forage type, or preferably by species, will result in a reliable estimation of the undigestible fraction through nonlinear approaches. The ability to estimate the undigestible fraction might preclude the need to conduct long-term fermentations $(240 \mathrm{~h})$ due to the high correlation with values obtained at $120 \mathrm{~h}$, but this is very much forage type-specific (legumes vs. grasses). All other parameters resulted in very low bias, slope, and random variation (Tables 7 and 8). The outcome of this work suggests the optimization in Vensim can become a routine tool to better define fiber fractions in forages for a better decision-making process for nutritionists.

After evaluating the global data set, it became apparent that, due to the more variable nature of the uNDF pool size and the apparent differences in the size and rate of the pdNDF 1 pool, it would be more effi-

Table 6. Relationship between the predicted and observed model parameters, mean bias (observed - predicted), mean squared prediction error (MSPE) per parameter, and respective distribution when using 48 and $96 \mathrm{~h}$ as intermediate fermentation time points and $240 \mathrm{~h}$ as the endpoint (unavailable NDF)

\begin{tabular}{|c|c|c|c|c|c|c|c|c|}
\hline Parameter $^{1}$ & Intercept & Slope & $\mathrm{R}^{2}$ & Mean bias ${ }^{2}$ & $\mathrm{MSPE}^{3}$ & \multicolumn{3}{|c|}{ Distribution of MSPE } \\
\hline $\operatorname{pdNDF}_{1}$ & 0.067 & 0.921 & 0.76 & -0.0081 & 0.1673 & 0.039 & 0.028 & 0.932 \\
\hline $\mathrm{k}_{1}$ & 0.000 & 0.950 & 0.92 & -0.0038 & 0.0034 & 0.425 & 0.020 & 0.555 \\
\hline $\mathrm{k}_{2}$ & 0.001 & 0.822 & 0.92 & -0.0009 & 0.0004 & 0.205 & 0.286 & 0.509 \\
\hline Unavailable NDF & -0.013 & 1.036 & 0.98 & -0.0041 & 0.0219 & 0.076 & 0.054 & 0.869 \\
\hline
\end{tabular}

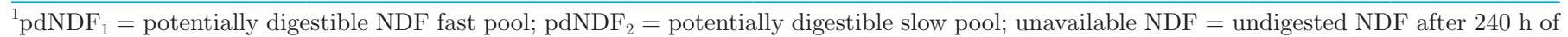
in vitro fermentation; $\mathrm{k}_{1}=$ digestion rate of the fast pool in percent per hour; $\mathrm{k}_{2}=$ digestion rate of the slow pool.

${ }^{2} \mathrm{NDF}^{-1}$ for $\mathrm{pdNDF}_{1}, \mathrm{pdNDF}_{2}$, and unavailable $\mathrm{NDF} ; \mathrm{h}^{-1}$ for $\mathrm{k}_{1}$ and $\mathrm{k}_{2}$.

${ }^{3}\left(\mathrm{NDF}^{-1}\right)^{2} \times 10^{2}$ for $\mathrm{pdNDF}_{1}, \mathrm{pdNDF}_{2}$, and unavailable NDF; $\left(\mathrm{h}^{-1}\right)^{2} \times 10^{2}$ for $\mathrm{k}_{1}$ and $\mathrm{k}_{2}$. 
Table 7. Relationship between the predicted and observed model parameters, mean bias (observed - predicted), mean squared prediction error (MSPE) per parameter, and respective distribution when using 30 and $120 \mathrm{~h}$ as fermentation time points and constraining unavailable NDF to forage-family-specific ranges

\begin{tabular}{|c|c|c|c|c|c|c|c|c|}
\hline Parameter $^{1}$ & Intercept & Slope & $\mathrm{R}^{2}$ & Mean bias ${ }^{2}$ & $\mathrm{MSPE}^{3}$ & \multicolumn{3}{|c|}{ Distribution of MSPE } \\
\hline $\mathrm{pdNDF}_{1}$ & 0.0944 & 0.8562 & 0.77 & 0.0181 & 0.2284 & 0.359 & 0.053 & 0.588 \\
\hline $\mathrm{k}_{1}$ & 0.0101 & 0.9010 & 0.76 & 0.0028 & 0.0071 & 0.296 & 0.056 & 0.648 \\
\hline $\mathrm{k}_{2}$ & 0.0023 & 0.8485 & 0.75 & -0.0014 & 0.0023 & 0.174 & 0.304 & 0.522 \\
\hline Unavailable NDF & 0.0157 & 0.9590 & 0.97 & 0.0054 & 0.0407 & 0.133 & 0.079 & 0.789 \\
\hline
\end{tabular}

${ }^{1} \mathrm{pdNDF}_{1}=$ potentially digestible NDF fast pool; $\mathrm{pdNDF}_{2}=$ potentially digestible slow pool; unavailable NDF $=$ undigested NDF after $240 \mathrm{~h}$ of in vitro fermentation; $\mathrm{k}_{1}=$ digestion rate of the fast pool in percent per hour; $\mathrm{k}_{2}=$ digestion rate of the slow pool.

${ }^{2} \mathrm{NDF}^{-1}$ for $\mathrm{pdNDF}_{1}$, pdNDF 2 , and unavailable NDF; $\mathrm{h}^{-1}$ for $\mathrm{k}_{1}$ and $\mathrm{k}_{2}$.

${ }^{3}\left(\mathrm{NDF}^{-1}\right)^{2} \times 10^{2}$ for $\mathrm{pdNDF}_{1}, \mathrm{pdNDF}_{2}$, and unavailable NDF; $\left(\mathrm{h}^{-1}\right)^{2} \times 10^{2}$ for $\mathrm{k}_{1}$ and $\mathrm{k}_{2}$.

cient and practical to run forage type-specific solutions. Therefore, we optimized all the same combinations of time points for each of the forage type, pooling forages within each type only, to determine if improvements in accuracy could be obtained. We recognized the limitations of a small number of forages per type, but the solutions appeared to be very robust and were lower in RMS than when generated using the entire data set. The optimal combination of time points for each forage type using either $240 \mathrm{~h}$ as an end point or when constraining uNDF to forage type-specific ranges, when ranked based on average $R^{2}$ and RMS, are in Tables 9 and 10 .

Overall, the results indicate that 36 (or 48) and $120 \mathrm{~h}$ is the optimal combination of time points for most forage types. Both BMR corn silages and alfalfas resulted in better goodness of fit when using 24 to 96 and 30 to $120 \mathrm{~h}$, respectively, most likely because of the time point where the $\mathrm{pdNDF}_{1}$ is exhausted. Grass hays and straws instead resulted in better estimations of pools and rates when residual at 36 to 96 or 48 to $96 \mathrm{~h}$ were used for the optimization, respectively. The prediction results appear to be dependent on when the fast pool is exhausted, most likely due to the determination of the inflection point.

The correlations among the time points demonstrate that, except between 6 and $36 \mathrm{~h} \mathrm{NDF}$, all correlations were significantly different than $0(P<0.05$; Table 11). Correlations among time points sequential to each other were quite high, and as the interval length between them increased the correlations decreased and the difference between the initial and the postfermentation aNDFom content increased as well. We found a high correlation among the later fermentation time points (Table 11), which supports the observation that the rate and pool size can be predicted from at least the 120-h fermentation end point if the 240-h aNDFom residue is not known, especially if the forage type can be identified. The pdNDF of immature grasses, such as high-quality pasture grass and most legumes, is exhausted by $120 \mathrm{~h}$, which helps improve the correlation between $120-$ and $240-\mathrm{h}$ residues (Table 11). However, sample identification, especially for commercial laboratories, is extremely difficult; thus, extending the fermentation to $240 \mathrm{~h}$ is considered essential to ensure proper quantification of the uNDF.

Table 8. Relationship between the predicted and observed model parameters, mean bias (observed - predicted), mean squared prediction error (MSPE) per parameter, and respective distribution when using 36 and $120 \mathrm{~h}$ as fermentation time points and constraining unavailable NDF to forage-family-specific ranges

\begin{tabular}{|c|c|c|c|c|c|c|c|c|}
\hline Parameter $^{1}$ & Intercept & Slope & $\mathrm{R}^{2}$ & Mean bias ${ }^{2}$ & $\mathrm{MSPE}^{3}$ & \multicolumn{3}{|c|}{ Distribution of MSPE } \\
\hline $\operatorname{pdNDF}_{1}$ & 0.0937 & 0.7954 & 0.72 & 0.0199 & 0.2273 & 0.317 & 0.150 & 0.533 \\
\hline $\mathrm{k}_{1}$ & -0.0098 & 0.8821 & 0.69 & 0.0033 & 0.0100 & 0.430 & 0.120 & 0.450 \\
\hline $\mathrm{k}_{2}$ & 0.0011 & 0.7819 & 0.71 & 0.0009 & 0.0039 & 0.282 & 0.308 & 0.410 \\
\hline Unavailable NDF & 0.0132 & 0.9102 & 0.90 & 0.0044 & 0.0538 & 0.113 & 0.039 & 0.848 \\
\hline
\end{tabular}

${ }^{1} \mathrm{pdNDF}_{1}=$ potentially digestible NDF fast pool; $\mathrm{pdNDF}_{2}=$ potentially digestible slow pool; unavailable NDF $=$ undigested NDF after $240 \mathrm{~h}$ of in vitro fermentation; $\mathrm{k}_{1}=$ digestion rate of the fast pool in percent per hour; $\mathrm{k}_{2}=$ digestion rate of the slow pool.

${ }^{2} \mathrm{NDF}^{-1}$ for $\mathrm{pdNDF}_{1}$, pdNDF 2 , and unavailable NDF; $\mathrm{h}^{-1}$ for $\mathrm{k}_{1}$ and $\mathrm{k}_{2}$.

${ }^{3}\left(\mathrm{NDF}^{-1}\right)^{2} \times 10^{2}$ for pdNDF $1, \mathrm{pdNDF}_{2}$, and unavailable NDF; $\left(\mathrm{h}^{-1}\right)^{2} \times 10^{2}$ for $\mathrm{k}_{1}$ and $\mathrm{k}_{2}$. 
Table 9. Optimal combinations of time points when using 2 time points in the curve plus $240 \mathrm{~h}$ as endpoint (unavailable NDF) and respective average $R^{2}$ and residual means squares (RMS) across forages within type ( $\mathrm{n}$ is number of forages per type)

\begin{tabular}{lcccc}
\hline Type & $\mathrm{n}$ & Combination & $\mathrm{R}^{2}$ & $\mathrm{RMS}$ \\
\hline Conventional corn silage & 8 & $36-120$ & 0.92 & 0.0012 \\
Brown midrib corn silage & 7 & $30-120$ & 0.93 & 0.0032 \\
Grasses & 6 & $36-96$ & 0.89 & 0.0041 \\
Straws and hays & 6 & $48-120$ & 0.88 & 0.0022 \\
Alfalfas & 7 & $24-96$ & 0.94 & 0.0010 \\
\hline
\end{tabular}

An improvement of the lag estimation is possible using another time point early in the fermentation, thus providing more information to the optimization. Constraining the lag to be the average per forage type during the optimization might improve the optimization. However, lag times can vary within and between laboratories depending on the in vitro procedure and on the rumen fluid handling. Results show that an unknown lag (within a range of 1 to $5 \mathrm{~h}$ ) will not bias the final estimation of pool sizes and rates; however, it is important that the laboratory know and understand the average lag time and if there is a variation by forage type. To understand lag, a laboratory should analyze a common forage multiple times for early time points, 1 , 2,4 , and $6 \mathrm{~h}$, and measure the aNDFom disappearance. The natural log of the unitized residue over time can be plotted and the rate of change (delta) can iteratively be determined taking the antilog of the difference from 0 to $6 \mathrm{~h}$.

According to Ellis et al. (1999), determination of uNDF should be included in all basic feedstuff analysis because it has a predictable digestibility; it can be used for the estimation of the pdNDF, as NDF minus $\mathrm{uNDF}$, and it has an important role in contributing to rumen digesta load. Furthermore, a close empirical relationship between silage UNDF and OM digestibility (Nousiainen et al., 2003) indicates that uNDF is a useful entity for the prediction of the nutritive value of forages. We demonstrated that prediction of the undi-
Table 10. Optimal combinations of time points when using 2 time points in the curve and constraining unavailable NDF to forage typespecific ranges and respective average $\mathrm{R}^{2}$ and residual means squares (RMS) across forages within type ( $\mathrm{n}$ is number of forages per group)

\begin{tabular}{lcccc}
\hline Type & $\mathrm{n}$ & Combination & $\mathrm{R}^{2}$ & RMS \\
\hline Conventional corn silage & 8 & $36-120$ & 0.88 & 0.0012 \\
Brown midrib corn silage & 7 & $30-120$ & 0.81 & 0.0032 \\
Grasses & 6 & $36-96$ & 0.73 & 0.0041 \\
Straws and hays & 6 & $48-120$ & 0.82 & 0.0022 \\
Alfalfas & 7 & $24-96$ & 0.93 & 0.0010 \\
\hline
\end{tabular}

gested fraction is possible if longer fermentation time points are not available by using forage type-specific ratios of uNDF to ADL (Tables 8 and 9).

Finally, for routine application when available, the data suggest that as long as one of the time points for each pdNDF pool is within the linear portion of the decay curve, the model will determine the optimum solution and provide rates of digestion for each respective pool; the model will also provide the pool size of the pdNDF fast and slow pool, along with the uNDF. The digestion time points necessary to capture most of the variation in typical northeastern United States, temperate forages were 30,120 , and $240 \mathrm{~h}$; however, other time points might be necessary if the forages are very immature, as in pasture grasses, or for nonforage fiber feeds without the maturity or capacity to create crosslinking between hemicellulose and lignin.

\section{CONCLUSIONS}

The calculation of $\mathrm{k}_{1}$ and $\mathrm{k}_{2}$ and the $\mathrm{pdNDF}_{1}$ and $\mathrm{pdNDF}_{2}$ presented here have the advantage of requiring minimum data to generate, and thus might be more easily implemented by commercial laboratories. As the calculations are direct and use more robust mathematical modeling procedures, they are simpler to implement because many observations are not required, although the user will need some understanding of the software and optimization procedures. The modeling approach

Table 11. Correlations matrix between the various time points of NDF digestibility

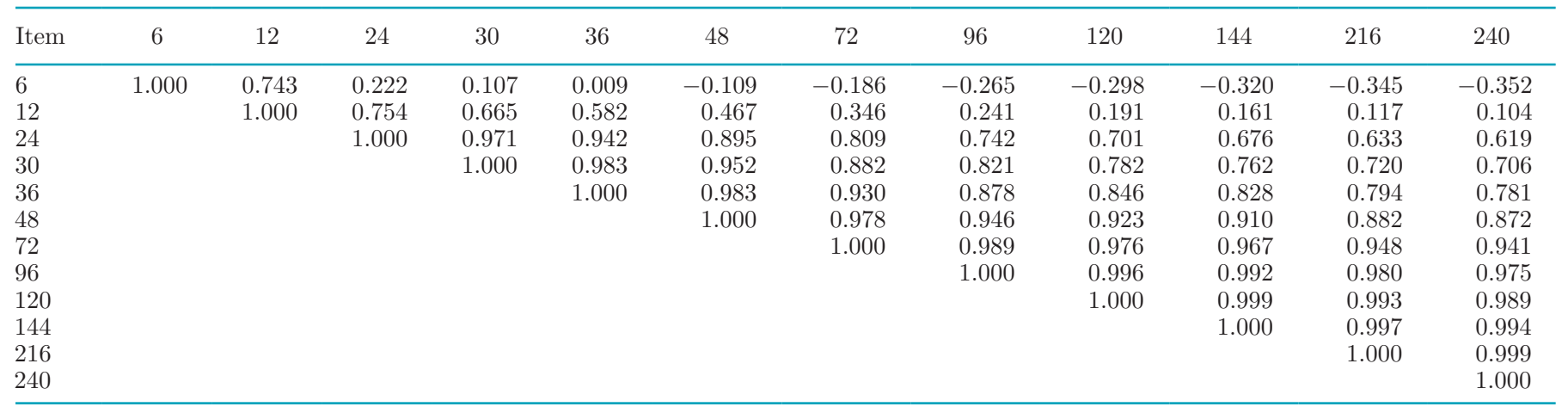


described in this paper should provide nutritionists with better information about the heterogeneity and digestibility of NDF and the dynamic nature of the pool sizes that might influence feed intake and energy yield. A larger data set of long-term fermentations with intermediate time points are needed to build a data set able to explain the variation in NDF pools sizes and within forage type, and this should be linked to the agronomic conditions the plants were grown under.

\section{ACKNOWLEDGMENTS}

Partial financial support for this work was received from Hatch Grant number 2007-08-127.

\section{REFERENCES}

Allen, M. S., and D. R. Mertens. 1988. Evaluating constraints on fiber digestion by rumen microbes. J. Nutr. 118:261-270. https://doi .org/10.1093/jn/118.2.261.

Bibby, J., and H. Toutenburg. 1977. Prediction and Improved Estimation in Linear Models. Wiley, New York, NY.

Chandler, J. A., W. J. Jewell, J. M. Gossett, P. J. Van Soest, and J. B. Robertson. 1980. Predicting methane fermentation biodegradability. Biotechnol. Bioeng. Symp. 10:93-107.

Dado, R. G., and M. S. Allen. 1996. Enhanced intake and production of cows offered ensiled alfalfa with higher neutral detergent fiber digestibility. J. Dairy Sci. 79:418-428. https://doi.org/10.3168/jds .S0022-0302(96)76381-6.

Danfær, A., P. Huhtanen, P. Udén, J. Sveinbjörnsson, H. Volden, E. Kebreab, J. Dijkstra, A. Bannink, W. J. J. Gerrits and J. France. 2006a. The Nordic dairy cow model KAROLINE - Model evaluation. Pages 407-415 in Nutrient Digestion and Utilization in Farm Animals: Modelling Approaches. E. Kebreab, J. Dijkstra, A. Bannink, W. Gerrits, J. France, ed. CABI Publishing, Wallingford, UK.

Danfær, A., P. Huhtanen, P. Udén, J. Sveinbjörnsson, H. Volden, E. Kebreab, J. Dijkstra, A. Bannink, W. J. J. Gerrits and J. France. 2006b. The Nordic dairy cow model KAROLINE-Model description. Pages 383-406 in Nutrient Digestion and Utilization in Farm Animals: Modelling Approaches. E. Kebreab, J. Dijkstra, A. Bannink, W. Gerrits, J. France, ed. CABI Publishing, Wallingford, UK.

Ellis, W. C., M. Mahlooji, and J. H. Matis. 2005. Models for estimating parameters of neutral detergent fiber digestion by ruminal microorganisms. J. Anim. Sci. 83:1591-1601. https://doi.org/10 $.2527 / 2005.8371591 x$.

Ellis, W. C., D. P. Poppi, J. H. Matis, H. Lippke, T. M. Hill, and F. M. Roquette Jr. 1999. Dietary-digestive-metabolic interactions determining the nutritive potential of ruminant diets. Pages 423-481 in Proc. 5th Int. Symp. Nutr. Herbivores. H. J. G. Jung and G. C. Fahey, Jr., ed. Am. Soc. Anim. Sci., Savoy, IL.

Fox, D. G., C. J. Sniffen, J. D. O'Connor, J. B. Russell, and P. J. Van Soest. 1992. A net carbohydrate and protein system for evaluating cattle diets: III. Cattle requirements and diet adequacy. J. Anim. Sci. 70:3578-3596. https://doi.org/10.2527/1992.70113562x.

Fox, D. G., L. O. Tedeschi, T. P. Tylutki, J. B. Russell, M. E. Van Amburgh, L. E. Chase, A. N. Pell, and T. R. Overton. 2004. The Cornell net carbohydrate and protein system model for evaluating herd nutrition and nutrient excretion. Anim. Feed Sci. Technol. 112:29-78. https://doi.org/10.1016/j.anifeedsci.2003.10.006.

Goering, H. K., and P. J. Van Soest. 1970. Forage Fiber Analyses (Apparatus, Reagents, Procedures, and some Applications). US Agricultural Research Service. Agric. Handbook 379. ARS, USDA, Washington, DC.
Grant, R. J., S. G. Haddad, K. J. Moore, and J. F. Pedersen. 1995. Brown midrib sorghum silage for midlactation dairy cows. J. Dairy Sci. 78:1970-1980. https://doi.org/10.3168/jds.S0022 -0302(95)76823-0.

Grant, R. J., and D. R. Mertens. 1992. Influence of buffer $\mathrm{pH}$ and raw corn starch addition on in vitro fiber digestion kinetics. J. Dairy Sci. 75:2762-2768. https://doi.org/10.3168/jds.S0022 -0302(92)78039-4.

Huhtanen, P., J. Nousiainen, and M. Rinne. 2006. Recent developments in forage evaluation with special reference to practical applications. Agric. Food Sci. 15:293-323. https://doi.org/10.2137/ 145960606779216317.

Huhtanen, P., A. Seppälä, S. Ahvenjärvi, and M. Rinne. 2008a. Prediction of in vivo NDF digestibility and digestion rate of potentially digestible NDF: Comparison of models. J. Anim. Sci. 86:26572669. https://doi.org/10.2527/jas.2008-0894.

Huhtanen, P., A. Seppälä, M. Ots, S. Ahvenjärvi, and M. Rinne. 2008b. In vitro gas production profiles to estimate extent and effective first-order rate of neutral detergent fiber digestion in the rumen. J. Anim. Sci. 86:651-659. https://doi.org/10.2527/jas.2007 -0246 .

Krizsan, S. J., L. Nyholm, J. Nousiainen, K. Südekum, and P. Huhtanen. 2012. Comparison of in vitro and in situ methods in evaluation of forage digestibility in ruminants. J. Anim. Sci. 90:3162-3173. https://doi.org/10.2527/jas.2011-4347.

Lucas, H. L. 1964. Stochastic elements in biological models: Their sources and significance. Pages 355-383 in Stochastic Models in Medicine and Biology. J. Gurland, ed. Univ. Wisconsin Press, Madison.

Mertens, D. R. 1973. Application of Theoretical Mathematical Models to Cell Wall Digestion and Forage Intake in Ruminants. Cornell University, Ithaca, NY.

Mertens, D. R. 1977. Dietary fiber components: Relationship to the rate and extent of ruminal digestion. Fed. Proc. 36:187-192.

Mertens, D. R. 1994. Regulation of forage intake. Pages 450-493 in Forage Quality, Evaluation, and Utilization. G. C. Fahey Jr., ed. Am. Soc. Agron., Madison, WI.

Mertens, D. R. 2002. Gravimetric determination of amylase-treated neutral detergent fiber in feeds with refluxing in beakers or crucibles: Collaborative study. J. AOAC Int. 85:1217-1240.

Mertens, D. R. 2005. Rate and extent of digestion. Pages 13-47 in Quantitative Aspects of Ruminant Digestion and Metabolism. 2nd ed. J. Dijkstra, J. M. Forbes, and J. France, ed. CABI Publishing, Cambridge, MA. https://doi.org/10.1079/9780851998145.0000

Mertens, D. R., and L. O. Ely. 1979. A dynamic model of fiber digestion and passage in the ruminant for evaluating forage quality. J. Anim. Sci. 49:1085-1095. https://doi.org/10.2527/jas1979 $.4941085 \mathrm{x}$

Mertens, D. R., and J. R. Loften. 1980. The effect of starch on forage fiber digestion kinetics in vitro. J. Dairy Sci. 63:1437-1446.

Moore, K. J., and J. H. Cherney. 1986. Digestion kinetics of sequentially extracted cell wall components of forages. Crop Sci. 26:12301235 .

Nousiainen, J., S. Ahvenjärvi, M. Rinne, M. Hellämäki, and P. Huhtanen. 2004. Prediction of indigestible cell wall fraction of grass silage by near infrared reflectance spectroscopy. Anim. Feed Sci. Technol. 115:295-311. https://doi.org/10.1016/j.anifeedsci .2004.03.004.

Nousiainen, J., M. Rinne, M. Hellämäki, and P. Huhtanen. 2003. Prediction of the digestibility of the primary growth of grass silages harvested at different stages of maturity from chemical composition and pepsin-cellulase solubility. Anim. Feed Sci. Technol. 103:97-111.

Oba, M., and M. S. Allen. 2000. Effects of brown midrib 3 mutation in corn silage on productivity of dairy cows fed two concentrations of dietary neutral detergent fiber: 1 . feeding behavior and nutrient utilization. J. Dairy Sci. 83:1333-1341. https://doi.org/10.3168/ jds.S0022-0302(00)75000-4.

Palmonari, A., A. Gallo, M. Fustini, G. Canestrari, F. Masoero, C. J. Sniffen, and A. Formigoni. 2016. Estimation of the indigestible 
fiber in different forage types. J. Anim. Sci. 94:248-254. https:// doi.org/10.2527/jas.2015-9649.

Piñeiro, G., S. Perelman, J. P. Guerschman, and J. M. Paruelo. 2008. How to evaluate models: Observed vs. predicted or predicted vs. observed? Ecol. Modell. 216:316-322. https://doi.org/10.1016/j .ecolmodel.2008.05.006.

Powell, M. J. D. 1964. An efficient method for finding the minimum of a function of several variables without calculating derivatives. Comput. J. 7:155-162.

Raffrenato, E., and L. J. Erasmus. 2013. Variability of indigestible $\mathrm{NDF}$ in $\mathrm{C} 3$ and $\mathrm{C} 4$ forages and implications on the resulting feed energy values and potential microbial protein synthesis in dairy cattle. S. Afr. J. Anim. Sci. 43:93-97.

Raffrenato, E., R. Fievisohn, K. W. Cotanch, R. J. Grant, L. E. Chase, and M. E. Van Amburgh. 2017. Effect of lignin linkages with other plant cell wall components on in vitro and in vivo neutral detergent fiber digestibility and rate of digestion of grass forages. J. Dairy Sci. 100:8119-8131. https://doi.org/10.3168/jds.2016-12364.

Raffrenato, E., D. A. Ross, and M. E. Van Amburgh. 2018. Development of an in vitro method to determine rumen undigested aNDFom for use in feed evaluation. J. Dairy Sci. 101:9888-9900. https: //doi.org/10.3168/jds.2018-15101.

Raffrenato, E., and M. Van Amburgh. 2011. Technical note: Improved methodology for analyses of acid detergent fiber and acid detergent lignin. J. Dairy Sci. 94:3613-3617. https://doi.org/10.3168/ jds.2010-3701.

Rinne, M., A. Olt, J. Nousiainen, A. Seppälä, M. Tuori, C. Paul, M. D. Fraser, and P. Huhtanen. 2006. Prediction of legume silage digestibility from various laboratory methods. Grass Forage Sci. 61:354-362. https://doi.org/10.1111/j.1365-2494.2006.00542.x.

Russell, J. B., J. D. O'Connor, D. G. Fox, P. J. Van Soest, and C. J. Sniffen. 1992. A net carbohydrate and protein system for evaluating cattle diets: I. ruminal fermentation. J. Anim. Sci. 70:35513561. https://doi.org/10.2527/1992.70113551x.

Sniffen, C. J., J. D. O'Connor, P. J. Van Soest, D. G. Fox, and J. B. Russell. 1992. A net carbohydrate and protein system for evaluating cattle diets: II. carbohydrate and protein availability. J. Anim. Sci. 70:3562-3577. https://doi.org/10.2527/1992.70113562x.
Theil, H. 1966. Applied Economic Forecasting. Rand McNally, Amsterdam, the Netherlands.

Tylutki, T. P., D. G. Fox, V. M. Durbal, L. O. Tedeschi, J. B. Russell, M. E. Van Amburgh, T. R. Overton, L. E. Chase, and A. N. Pell 2008. Cornell net carbohydrate and protein system: A model for precision feeding of dairy cattle. Anim. Feed Sci. Technol. 143:174202. https://doi.org/10.1016/j.anifeedsci.2007.05.010.

Uden, P. 2006. Recovery of insoluble fibre fractions by filtration and centrifugation. Anim. Feed Sci. Technol. 129:316-328. https://doi .org/10.1016/j.anifeedsci.2006.01.011.

Van Amburgh, M. E., E. Collao-Saenz, R. Higgs, D. Ross, E. Recktenwald, E. Raffrenato, L. Chase, T. Overton, J. Mills, and A. Foskolos. 2015. The Cornell Net Carbohydrate and Protein System Updates to the model and evaluation of version 6.5. J. Dairy Sci. 98:6361-6380. https://doi.org/10.3168/jds.2015-9378.

Van Amburgh, M. E., P. J. Van Soest, J. B. Robertson, and W. F. Knaus. 2003. Corn silage neutral detergent fiber: Refining a mathematical approach for in vitro rates of digestion. Pages 99-108 in Proc. Cornell Nutr. Conf. Syracuse, NY. Dept. of Anim. Sci., Cornell University, Ithaca, NY.

Van Milgen, J., M. R. Murphy, and L. L. Berger. 1991. A compartmental model to analyze ruminal digestion. J. Dairy Sci. 74:2515-2529. https://doi.org/10.3168/jds.S0022-0302(91)78429-4.

Van Soest, P. J. 1994. Nutritional Ecology of the Ruminant. Cornell University Press, Ithaca, NY.

Van Soest, P. J. 2015. The Detergent System for Analysis of Foods and Feeds. Cornell University, Ithaca, NY.

Van Soest, P. J., M. E. Van Amburgh, J. B. Robertson, and W. F. Knaus. 2005. Validation of the 2.4 times lignin factor for ultimate extent of NDF digestion, and curve peeling rate of fermentation curves into pools. Pages 139-149 in Proc. Cornell Nutr. Conf., Syracuse, NY. Dept. of Anim. Sci., Cornell University, Ithaca, NY. Villuendas, F., and J. Pelayo. 1987. A method to fit composite exponential decay curves by reduction of the searching space dimension. Nucl. Instrum. Methods Phys. Res. A 253:288-293. 